\title{
Virulence Characterization of Puccinia striiformis f. sp. tritici Using a New Set of $Y r$ Single-Gene Line Differentials in the United States in 2010
}

Anmin Wan, Department of Plant Pathology, Washington State University, Pullman, WA 99164-6430; and Xianming Chen, United States Department of Agriculture-Agricultural Research Service, Wheat Genetics, Quality, Physiology, and Disease Research Unit and Department of Plant Pathology, Washington State University, Pullman

\begin{abstract}
Wan, A. M., and Chen, X. M. 2014. Virulence characterization of Puccinia striiformis f. sp. tritici using a new set of $Y r$ single-gene line differentials in the United States in 2010. Plant Dis. 98:1534-1542.

Puccinia striiformis f. sp. tritici causes stripe rust (yellow rust) of wheat and is highly variable in virulence toward wheat with racespecific resistance. During 2010, wheat stripe rust was the most widespread in the recorded history of the United States, resulting in large-scale application of fungicides and substantial yield loss. A new differential set with 18 yellow rust $(Y r)$ single-gene lines was established and used to differentiate races of $P$. striiformis f. sp. tritici, which were named as race PSTv in distinction from the PST races identified in the past. An octal system was used to describe the virulence and avirulence patterns of the PSTv races. From 348 viable P. striiformis f. sp. tritici isolates recovered from a total of 381 wheat and grass stripe rust samples collected in 24 states, 41 races, named PSTv-1 to PSTv-41, were identified using the new set of $18 \mathrm{Yr}$ single-

gene differentials, and their equivalent PST race names were determined on the previous set of 20 wheat cultivar differentials. The frequencies and distributions of the races and their virulences were determined. The five most predominant races were PSTV-37 (34.5\%), PSTv-11 (17.5\%), PSTv-14 (7.2\%), PSTv-36 (5.2\%), and PSTv-34 (4.9\%). PSTv-37 was distributed throughout the country while PSTv11 and PSTv-14 were almost restricted to states west of the Rocky Mountains. The races had virulence to 0 to 13 of the $18 \mathrm{Yr}$ genes. Frequencies of virulences toward resistance genes $\operatorname{Yr} 6, \operatorname{Yr} 7, \mathrm{Yr} 8, \mathrm{Yr} 9$, $Y r 17, Y r 27, Y r 43, Y r 44, Y r T r 1$, and $Y r E x p 2$ were high (67.0 to 93.7\%); those to $\mathrm{Yrl}(32.8 \%)$ and YrTye (31.3\%) were moderate; and those to $\operatorname{Yr} 10, Y r 24, Y r 32$, and $\operatorname{YrSP}$ were low (3.4 to 5.7\%). All of the isolates were avirulent to $\mathrm{Yr} 5$ and $\mathrm{Yr} 15$.
\end{abstract}

Stripe (or yellow) rust of wheat, caused by Puccinia striiformis f. sp. tritici Erikss., is a major disease worldwide and causes huge yield losses, particularly in the regions where favorable weather conditions dominate and susceptible cultivars are grown $(1,3,22$, $31,35,36)$. The disease has caused frequent damage in the western United States since late 1950 s and has become a nationwide problem since $2000(3,12,13,17,22)$. Yield loss of wheat caused by stripe rust was estimated as $1.08,2.42$, and 2.00 million metric tons in 2001, 2003, and 2005, respectively in the United States (http:// iapreview.ars.usda.gov/SP2UserFiles/ad_hoc/36400500Smallgrainl ossesduetorust/SmalGraiSu-09-30-2010_new_format.pdf and http: //striperust.wsu.edu/generalInformation/puccinia-striiformis-im pacts.html), even after millions of dollars were spent on fungicide application to reduce the damage.

Corresponding author: X. M. Chen, E-mail: xianming@wsu.edu

* The $\boldsymbol{e}$-Xtra logo stands for "electronic extra" and indicates that three supplementary tables are available online.

PPNS Number 0610, Department of Plant Pathology, College of Agricultural, Human, and Natural Resource Sciences, Agricultural Research Center, Project Number WNP00663 (Projects 13C-3061-3925 and 13C-30613232), Washington State University, Pullman 99164-6430.

Mention of trade names or commercial products in this publication is solely for the purpose of providing specific information and does not imply recommendation or endorsement by the United States Department of Agriculture (USDA) Agricultural Research Service. USDA is an equal opportunity provider and employer.

Accepted for publication 3 May 2014.

http://dx.doi.org/10.1094/PDIS-01-14-0071-RE

This article is in the public domain and not copyrightable. It may be freely reprinted with customary crediting of the source. The American Phytopathological Society, 2014.
In 2010, stripe rust was widespread in the United States and Canada. Based on our observations and reports from collaborators, stripe rust of wheat was observed in 31 states in the United States and four provinces (Ontario, Manitoba, Alberta, and British Columbia) in Canada. The disease occurred relatively early in 2010, with the first report in early February in Texas, and the disease became severe and extensive by late February. In March, wheat stripe rust was reported in Louisiana, Arkansas, western Washington, and California; and became widespread in Louisiana by middle March. In April, the disease was observed in Mississippi, Oklahoma, Kansas, Nebraska, Virginia, and eastern Washington. In May, the disease was reported in Illinois, Indiana, Wisconsin, Maryland, Delaware, South Dakota, and Colorado. In June, it was found in New York, Ontario and Manitoba (Canada), Montana, Minnesota, North Dakota, and Idaho. The appearance of the disease in states such as Kentucky, Maryland, Delaware, and New York, where the disease has been infrequent in the past, indicated the unusually wide distribution. Wheat stripe rust distribution in 2010 was more wide spread than in $2005(4,13)$, making a new record of broad occurrence in the United States and Canada.

The stripe rust epidemic in 2010 resulted in wide application of foliar fungicides and major yield loss, especially in the Great Plains and the western states. Kansas, Oregon, and Texas had highest estimated percentage-wise yield losses, 10\%; and Nebraska, Oklahoma, Montana, and Louisiana also suffered $4-7 \%$ yield losses. The United States Department of Agriculture-Agricultural Research Service Cereal Disease Laboratory website (http://iapre view.ars.usda.gov/SP2UserFiles/ad_hoc/36400500Smallgrainlosses duetorust/SmalGraiSu-09-30-2010_new_format.pdf) provides the estimated percentage of yield loss on winter or spring wheat in each state. Nine states (Kansas, Texas, Montana, Oregon, Oklahoma, Nebraska, Washington, Idaho, and Colorado) had estimated yield losses of more than one million bushels. Nationally, stripe rust caused wheat grain loss of $4.36 \%$ or 2.606 million metric tons (equivalent to 95.769 million bushels) (http://striperust.wsu.edu), worth more than $\$ 670$ million. In addition, several hundred million dollars were used for fungicide application; for instance, Wash- 
ington State alone spent an estimated \$27 million (X. M. Chen, unpublished data).

Growing resistant cultivars is the most effective, economical, easy to use, and environmentally friendly approach to manage stripe rust. However, the rapid development of new virulent races in the pathogen population can overcome resistance in cultivars and often results in high yield loss $(3,4,12,13,22,24)$. Since 2000 , more than $80 P$. striiformis $\mathrm{f}$. sp. tritici races have been identified and four major changes of predominant races have occurred in the pathogen population $(3,4,12,13,34)$. As the consequence of the first wave of major race changes that occurred in 2000 to 2002, represented by new and predominant races PST-78 and PST-80, many cultivars with yellow rust $(Y r)$ gene $\operatorname{Yr} 9$ became susceptible $(3,12)$. The second major change in virulence occurred during 2003 to 2006, when races PST-100 and PST-102 with virulence to racespecific all-stage resistance genes in 'Stephens' ( $Y r 3 a, Y r S$, and YrSte) and 'Yamhill' (Yr2, Yr4a, and YrYam) were predominant $(3,4)$. During the third change in 2006 to 2009, races PST-114 and PST-116, virulent to 'Moro' (YrlO and YrMor), 'Paha' (YrPal, $Y r P a 2$, and $Y r P a 3)$, and 'Tres' (YrTr1 and $Y r T r 2)$, became predominant (13). As a result, cultivars with one or more of these genes became susceptible. The fourth wave, represented by the development of a group of races such as PST-127, PST-138, and PST-139, has taken place since 2009 and, as the result, 'Tyee' (YrTye) and 'Hyak' (Yrl7 and YrTye), which were susceptible to predominant races in the middle 1980s to middle 1990s but were resistant to races predominant in the late 1990s to middle 2000s, have become susceptible again $(13,34)$. The changes and shifts of these major races have also reduced total resistance levels in many cultivars as the predominant races have adapted to the race-specific all-stage resistance and left race-nonspecific but partial high-temperature adult-plant (HTAP) resistance to work $(3,4,13,34)$. As a result, many cultivars no longer express a high level of resistance and now require fungicide applications under high stripe rust pressure. For instance, the severe epidemic in 2010 caused an average yield loss of more than $13 \%$ on commercial winter wheat cultivars and more than $23 \%$ on commercial spring wheat cultivars in Washington State. Therefore, monitoring distribution and frequency changes of virulence toward the $\mathrm{Yr}$ genes is important for selecting cultivars with adequate resistance to grow in specific geographic regions and for developing new cultivars with durable and a high-level of resistance.

Since the $1960 \mathrm{~s}$, races of $P$. striiformis f. sp. tritici in the United States have been differentiated using a set of wheat cultivars, and the number of differential lines have been increased several times to the most recent set of 20 cultivars $(3,12,13,22,24,25)$. The additions of cultivars to the differential set have allowed identification of new races virulent on previously resistant cultivars. For example, the addition of the $\operatorname{Yr} 9$ single-gene line to the differential set in the year 2000 allowed the identification of new races PST-78 and PST-80 in that year (12). The $\operatorname{Yr} 9$ virulence in these races and their subsequently evolved races made many cultivars with resistance gene $Y r 9$ in states east of the Rocky Mountains become susceptible $(3,4)$. To our knowledge, $\operatorname{Yr} 9$ was the only known stripe rust resistance gene used in wheat cultivars in the eastern United States before the year 2000. The use of $\operatorname{Yr} 9$ in breeding programs in the region was inadvertent because the gene is linked with $\operatorname{Sr} 31, \operatorname{Lr} 26$, and $P m 8$ for resistance to stem rust, leaf rust, and powdery mildew, respectively, from the 1BL.1RS wheat-rye translocation lines (3). Since the 2000 epidemic, many breeding programs in the eastern United States also have intentionally developed stripe-rust-resistant wheat cultivars, using known genes such as $\operatorname{Yr} 5, \operatorname{Yr} 15, \mathrm{Yr} 17$, and Yr18 and resistant germplasm with unknown genes. The wider distribution and more frequent occurrence of stripe rust after 2000 have resulted in a more complex population of the pathogen in the United States than before $2000(3,4,13)$.

Most cultivars in the previous differential set were from the western United States, because wheat stripe rust was a major disease in this region $(3,12,13,22,24)$. The set of differentials may not adequately differentiate races for the $P$. striiformis f. sp. tritici population in the eastern United States. Moreover, most cultivars used in the original differential set have two or more genes for stripe rust resistance, which made it difficult to identify virulence to a particular resistance gene. Single-gene lines have been used to differentiate races of the wheat leaf rust $(P$. triticina) and stem rust (P. graminis f. sp. tritici) pathogens for many years $(18,28,29)$ but those for stripe rust resistance genes were not available until recently. Wellings et al. (37) developed more than a dozen $\mathrm{Yr}$ nearisogenic lines (NILs) and our program developed several singlegene lines (14), and these lines can be used for differentiating $P$. striiformis f. sp. tritici races. The objectives of this study were to (i) establish a $P$. striiformis $\mathrm{f}$. sp. tritici race identification system using $Y r$ single-gene lines and (ii) identify $P$. striiformis f. sp. tritici races and determine their distribution and frequencies using the new system.

\section{Materials and Methods}

Stripe rust monitoring and sample collections. Stripe rust was monitored by the authors in the Pacific Northwest and by collaborators and growers throughout the United States. Samples of stripe-rust-infected leaves were collected from commercial fields and nurseries throughout wheat-growing areas and sent to this lab for characterization. In general, one or more leaves with uredia from a single cultivar or line at a field site were collected as one sample, put into a glassine or paper envelope, and sent mostly via overnight delivery to our lab because the pathogen can lose viability quickly. After samples were received, collection date and location (city, county, and state), host (wheat or grass), and cultivar, growth stage, rust prevalence (percentage of plants infected), rust severity (percentage of leaf area infected), and infection type (IT) were recorded whenever possible. The samples were kept dry at $4^{\circ} \mathrm{C}$ until used.

Obtaining and storing isolates. Soft white winter wheat 'Nugaines', susceptible to all $P$. striiformis f. sp. tritici isolates at the seedling stage, was inoculated with urediniospores from samples to obtain initial isolates. Standard procedures and conditions were used for inoculating, growing plants before and post inoculation, and collecting and storing urediniospores, as previously described $(12,13,24)$. Seedlings at the two-leaf stage were used for inoculation with urediniospores from sample leaves. Inoculated plants were kept in a dew chamber at $10^{\circ} \mathrm{C}$ for $24 \mathrm{~h}$ in the dark and then transferred to a growth chamber with a diurnal temperature cycle that gradually changed from $4{ }^{\circ} \mathrm{C}$ at 2:00 a.m. to $20^{\circ} \mathrm{C}$ at 2:00 p.m. with 16-h photoperiod, as previously described $(12,13)$. Plants inoculated with each sample were isolated using a booth to avoid cross contamination. Urediniospores were collected using a vacuum spore collector beginning 16 days after inoculation. These spores were used to test on the set of wheat differential lines to identify races and stored in liquid nitrogen as original isolates, with one original isolate per sample.

For an original isolate that appeared to be a new race in the initial differential test, subisolates were obtained by inoculating urediniospores on one to three differential lines selected based on the initial tests to purify the spores. The urediniospores collected from each of the selected differentials, which served as key differentials to separate the virulence patterns from similar but different patterns of already identified races, were treated as a subisolate that could be different from the original isolate and the other subisolates from the same original isolate. For an original or subisolate that was identified as a new race, a single-uredium isolate was obtained by transferring urediniospores from only one uredium onto leaves of a key differential line using a very fine paint brush. The single-uredium isolate is considered more genetically pure than the original or subisolate and, therefore, was used as a type isolate for designating a race. Urediniospores were dried in a desiccator kept at $4^{\circ} \mathrm{C}$ for at least 2 days before storing in sealed foil bags at $4^{\circ} \mathrm{C}$ for short-term storage (up to 4 months) or in liquid nitrogen for longterm storage.

Testing isolates on differentials and recording IT data. Recovered fresh urediniospores or those kept at $4^{\circ} \mathrm{C}$ for less than 2 
months for an original, sub-, or single-uredium isolate were used to inoculate differentials, as previously described $(12,13,34)$. For all $P$. striiformis f. sp. tritici isolates, a new set of differential lines were used, and supplemental lines and the previous set of differentials were also used for selected isolates to provide additional information for each race, as described below.

ITs were recorded at 20 to 22 days after inoculation based on a 0-to-9 scale (24). IT data were converted to avirulence or virulence. An isolate was considered avirulent on a specific differential line when there were no symptoms (IT 0) or there were necrotic or chlorotic flecks (IT 1), necrotic or chlorotic blotches without sporulation (IT 2), or necrotic or chlorotic blotches with only a trace to moderate sporulation (ITs 3 to 6). An isolate was considered to be virulent if it caused abundant sporulation, with or without necrosis or chlorosis (ITs 7, 8, or 9) $(30,34)$.
Repeated tests were conducted for isolates showing virulence patterns different from previous identified races. Two or more repeats were done with sub- or single-uredium isolates to confirm the virulence or avirulence patterns of new races.

Establishment of a differential and nomenclature system for $P$. striiformis f. sp. tritici races. In total, $25 \mathrm{Yr}$ single-gene lines of wheat were initially used to test $P$. striiformis $\mathrm{f}$. sp. tritici isolates for virulence and avirulence (30; A. M. Wan and X. M. Chen, unpublished data). Based on the reactions of the total of 348 viable $P$. striiformis f. sp. tritici isolates collected during 2010, 18 single $\mathrm{Yr}$ gene wheat lines were selected to serve as a core set of differentials (Table 1). Seven wheat lines or cultivars (Table 1) were used as a set of supplementary differentials for comparison with races in other regions of the world. To provide continuity with the previous set of differentials and race names, isolates of races identified with

Table 1. Wheat genotypes used as differentials to distinguish races of Puccinia striiformis f. sp. tritici in the United States

\begin{tabular}{|c|c|c|c|c|}
\hline Differential number & Name $^{a}$ & Yr gene ga $^{a}$ & Genotype ID number & Type \\
\hline \multicolumn{5}{|l|}{ Core set } \\
\hline 1 & AvSYr1NIL & Yrl & WG00003 & Spring \\
\hline 2 & AvSYr5NIL & $\operatorname{Yr} 5$ & WG00004 & Spring \\
\hline 3 & AvSYr6NIL & Yr6 & WG00014 & Spring \\
\hline 4 & AvSYr7NIL & $Y r 7$ & WG00005 & Spring \\
\hline 5 & AvSYr8NIL & $Y r 8$ & WG00006 & Spring \\
\hline 6 & AvSYr9NIL & $\operatorname{Yr} 9$ & WG00007 & Spring \\
\hline 7 & AvSYr10NIL & Yr10 & WG00008 & Spring \\
\hline 8 & AvSYr15NIL & Yr15 & WG00009 & Spring \\
\hline 9 & AvSYr17NIL & $\operatorname{Yr} 17$ & WG00010 & Spring \\
\hline 10 & AvSYr24NIL & $\operatorname{Yr} 24$ & WG00016 & Spring \\
\hline 11 & AvSYr27NIL & Yr27 & WG00018 & Spring \\
\hline 12 & AvSYr32NIL & Yr32 & WG00031 & Spring \\
\hline 13 & AvS/IDO377s (F3-41-1) & Yr43 & WG00097 & Spring \\
\hline 14 & AvS/Zak (1-1-35-line1) & Yr44 & WG00098 & Spring \\
\hline 15 & AvSYrSPNIL & $Y r S P$ & WG00019 & Spring \\
\hline 16 & AvSYrTres1NIL & $Y r \operatorname{Tr} 1$ & WG00020 & Spring \\
\hline 17 & AvS/Exp 1/1-1 Line 74 & YrExp2 & WG00099 & Spring \\
\hline 18 & Tyee & YrTye & CI 017773 & Winter \\
\hline \multicolumn{5}{|l|}{ Supplementary set } \\
\hline $\mathrm{S} 1$ & Kalyansona & $Y r_{2}$ & PI 376839 & Spring \\
\hline S2 & Vilmorin 23 & Yr4a, YrV23 & PI 125093 & Winter \\
\hline S3 & Hybrid 46 & $\mathrm{Yr} 4 b, \mathrm{YrH} 46$ & PI 164755 & Winter \\
\hline S4 & Hugenoot & Yr25 & PI 591944 & Winter \\
\hline S5 & AvSYr28NIL & $\operatorname{Yr} 28$ & WG00032 & Spring \\
\hline S6 & AvSYr31NIL & $\operatorname{Yr} 31$ & WG00034 & Spring \\
\hline S7 & AvSYrANIL & $Y r A$ & WG00002 & Spring \\
\hline \multicolumn{5}{|l|}{ Old set ${ }^{\mathrm{c}}$} \\
\hline 1 & Lemhi & $\operatorname{Yr} 21$ & CI 011415 & Spring \\
\hline 2 & Chinese 166 & Yrl & CI 011765 & Winter \\
\hline 3 & Heines VII & Yr2, YrHVII & PI 201195 & Winter \\
\hline 4 & Moro & Yr10, YrMor & CI 013740 & Winter \\
\hline 5 & Paha & YrPa1, YrPa2, YrPa3 & CI 014485 & Winter \\
\hline 6 & Druchamp & Yr3a, YrD, YrDru & CI 013723 & Winter \\
\hline 7 & AvSYr5NIL & Yr5 & YR 00004 & Spring \\
\hline 8 & Produra & $\operatorname{YrPr} 1, \operatorname{YrPr} 2$ & CI 017460 & Spring \\
\hline 9 & Yamhill & $\mathrm{Yr} 2, \mathrm{Yr} 4 a, \mathrm{YrYam}$ & CI 014563 & Winter \\
\hline 10 & Stephens & Yr3a, YrS, YrSte & CI 017596 & Winter \\
\hline 11 & Lee & $Y r 7, Y r 22, Y r 23$ & CI 012488 & Spring \\
\hline 12 & Fielder & $\operatorname{Yr} 6, \operatorname{Yr} 20$ & CI 017268 & Spring \\
\hline 13 & Tyee & YrTye & CI 017773 & Winter \\
\hline 14 & Tres & $\operatorname{YrTr} 1, \operatorname{YrTr} 2$ & CI 017917 & Winter \\
\hline 15 & Hyak & Yr17, YrTye & PI 511674 & Winter \\
\hline 16 & Express & YrExp1, YrExp2 & DA 984034 & Spring \\
\hline 17 & AvSYr8NIL & $\operatorname{Yr} 8$ & YR 000008 & Spring \\
\hline 18 & AvSYr9NIL & $\operatorname{Yr} 9$ & YR 000009 & Spring \\
\hline 19 & Clement & $\mathrm{Yr} 9, \mathrm{YrCle}$ & PI 518799 & Winter \\
\hline 20 & Compair & $\operatorname{Yr} 8, \operatorname{Yr} 19$ & PI 325843 & Spring \\
\hline
\end{tabular}

${ }^{a}$ The yellow rust $(Y r)$ gene near-isogenic lines (NILs) AvSYr1NIL, AvSYr5NIL, AvSYr6NIL, AvSYr7NIL, AvSYr8NIL, AvSYr9NIL, AvSYr10NIL, AvSYr17NIL, AvSYr24NIL, AvSYr27NIL, AvSYr32NIL, AvSYrSPNIL, AvSTr1NIL, AvSYr28NIL, AvSYr31NIL, and AvSYrANIL in the 'Avocet Susceptible' (AvS) background were developed by the Plant Breeding Institute, University of Sydney, Australia (37). AvS/IDO377s (F3-41-1), AvS/Zak (11-35-line 1), and AvS/Exp 1/1-1 Line 74 are recombinant inbred lines developed by the United States Department of Agriculture-Agricultural Research Service, Pullman, WA, from crosses of IDO377s, Zak, and Express, respectively, with AvS (14,20,33). Refer to Chen et al. (11) for YrTye in Tyee; Chen and Line (9) and Chen et al. (5) for the $\mathrm{Yr}$ genes in Vilmorin 23 and Hybrid 46; and Ravi Singh (personal communication) for $Y r 2$ in Kalyansona.

${ }^{\mathrm{b}} \mathrm{CI}=$ Crop Index number, PI = Plant Identification number, and $Y r=$ yellow rust resistance gene line number.

${ }^{c}$ Refer to Chen et al. (12) and Chen et al. (13) for the old set of wheat differentials. 
the new set of $18 \mathrm{Yr}$ single-gene differentials were also tested on the previous set of 20 cultivar or line differentials $(3,4,12,13,34)$.

Because new differentials were developed, the nomenclature of P. striiformis f. sp. tritici races was modified. First, the number system, similar to the previous PST series $(3,12)$, was used with a "PSTv" prefix which designates a specific race of virulence or avirulence response on the differential set. For example, PSTv-1 is given to a race which is virulent to $Y r l$ and avirulent to the remaining 17 Yr gene lines in the new differential set. The prefix "PSTv" stands for $P$ striiformis $\mathrm{f}$. sp. tritici virulence. The "v" is included in the prefix is to distinguish the new race names from the previous "PST" races.

Second, an octal system, which is similar to the letter-coding systems for naming races of $P$. graminis f. sp. tritici (15) and $P$. triticina (18), was used for coding $P$. striiformis f. sp. tritici races. The $18 Y r$ single-gene differentials were grouped into six sets, each with 3 differentials (Table 2). Numbers 0 to 7 were used to code all

Table 2. Key for designating octal codes of races of Puccinia striiformis $\mathrm{f}$. sp. tritici

\begin{tabular}{llll}
\hline Set, code & & Yr gene $^{\mathbf{a}}$ & \\
\hline Differential & & & \\
1 & $Y r 1$ & $Y r 5$ & $Y r 6$ \\
2 & $Y r 7$ & $Y r 8$ & $Y r 9$ \\
3 & $Y r 10$ & $Y r 15$ & Yr17 \\
4 & $Y r 24$ & $Y r 27$ & Yr32 \\
5 & $Y r 43$ & $Y r 44$ & YrSP \\
6 & $Y r T r 1$ & $Y r E x p 2$ & YrTye \\
Octal number ${ }^{\mathrm{b}}$ & & & \\
0 & $\mathrm{~A}$ & $\mathrm{~A}$ & $\mathrm{~A}$ \\
1 & $\mathrm{~V}$ & $\mathrm{~A}$ & $\mathrm{~A}$ \\
2 & $\mathrm{~A}$ & $\mathrm{~V}$ & $\mathrm{~A}$ \\
3 & $\mathrm{~A}$ & $\mathrm{~A}$ & $\mathrm{~V}$ \\
4 & $\mathrm{~V}$ & $\mathrm{~V}$ & $\mathrm{~A}$ \\
5 & $\mathrm{~V}$ & $\mathrm{~A}$ & $\mathrm{~V}$ \\
6 & $\mathrm{~A}$ & $\mathrm{~V}$ & $\mathrm{~V}$ \\
7 & $\mathrm{~V}$ & $\mathrm{~V}$ & $\mathrm{~V}$ \\
\hline
\end{tabular}

${ }^{\mathrm{a}} \mathrm{A}=$ avirulent and $\mathrm{V}=$ virulent.

${ }^{b}$ Octal number in race formula. eight possible virulence or avirulence patterns for each set of three differentials. For each race (virulence patterns on the 18 differential lines), a code of six digits can be obtained.

Determination of frequencies and distributions of races. The frequency of each race identified was calculated and distributions were summarized for the entire country and for each of the 12 epidemiological regions (Fig. 1), as previously described $(3,13,34)$.

\section{Results}

Identification of $\boldsymbol{P}$. striiformis $\mathbf{f}$. sp. tritici races. Based on reactions of $348 \mathrm{P}$. striiformis f. sp. tritici isolates on the $18 \mathrm{Yr}$ singlegene differentials (Supplementary Table S1), 41 races, designated as PSTv-1 to PSTv-41 (Table 3), were identified. These races were also coded as 100000 (for PSTv-1) to 375744 (for PSTv-41) using the octal system (Table 3). Their virulent and avirulent reactions on the $18 \mathrm{Yr}$ single-gene differentials are provided in Supplementary Table S2 and on the 7 supplementary differentials are provided in Supplementary Table S3. Among the 41 PSTv races, PSTv-18 (000000) has the narrowest virulence spectrum, with avirulence to all of the $18 \mathrm{Yr}$ genes in the differential set, while PSTv-41 (375744) has the widest virulence spectrum, virulent to 13 of the 18 genes (Table 3). None of the races were virulent to $\operatorname{Yr} 5$ and Yr15.

The equivalent PST races of the PSTv races are given in Table 3, based on reactions of the representing isolates on the previous 20 wheat cultivar or line differentials. For example, the isolate for PSTv-1 (100000) was identified as PST-21; isolates of both PSTv11 (573246) and PSTv-14 (573247) were identified as either PST127 or PST-139; those of PSTv-37 (373244) were identified as either PST-100 or PST-131; and those of PSTV-40 (371744) were identified as either PST-114 or PST-116.

On the supplementary differentials, all of the 41 PSTv races were virulent on 'Hugenoot' (Yr25), 'AvSYr31NIL' (Yr31), and 'AvSYrANIL' ( $Y r A)$; 40 were virulent on 'AvSYr28NIL' (Yr28); 37 virulent on 'Kalyansona' (Yr2); 32 virulent on 'Vilmorin 23' (Yr4a and $\mathrm{YrV23}$ ); and 9 virulent on 'Hybrid 46' ( $\mathrm{Yr} 4 \mathrm{~b}$ and $\mathrm{YrH} 46$ ).

Frequencies and distributions of PSTv races. The frequencies of each race ranged from 0.29 to $34.48 \%$. The five most predominant races were PSTv-37 (34.48\%), PSTv-11 (17.53\%), PSTv-14

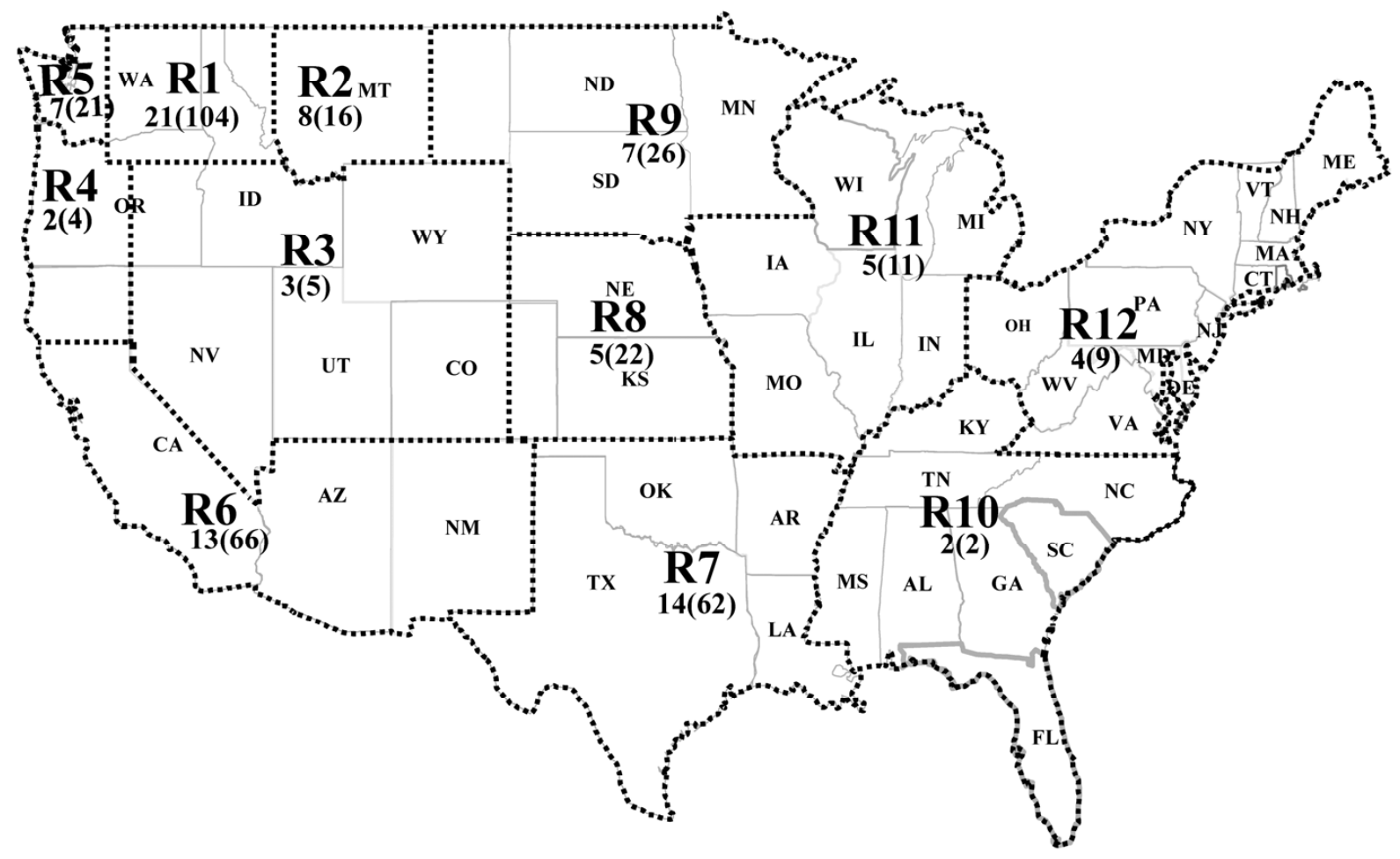

Fig. 1. Numbers of samples in parentheses and numbers of races in the 12 epidemiological regions (R1 to R12) in the United States in 2010. 
(7.18\%), PSTv-36 (370244) (5.17\%), and PSTv-34 (373224) $(4.89 \%)$. The remaining 37 races all had frequencies less than $4 \%$ (Table 3). The distributions of the PSTv races in various states are shown in Table 3 and the number of races detected in each of the 12 epidemic regions (Fig. 1) and the frequencies of races in each region are presented in Table 4.

In general, races with a high frequency also tended to be widely distributed. The most frequently identified race, PSTv-37, was detected in 16 states; and the second (PSTv-11), third (PSTV-14), fourth (PSTv-36), and fifth (PSTv-34) were detected in 4, 5, 10, and 7 states, respectively. Of the 41 races, 25 were identified from isolates of only one state (Table 3 ). The number of races and their frequencies also varied among the 12 epidemic regions (Table 4; Fig. 1). Region 1 had 21 races, with PSTv-11 (50.9\%) as the most frequent race. Region 2 had eight races, with PSTv-14 (37.5\%) as the most frequent race. Region 3 had three races, with relatively similar frequencies. Region 4 had only two races, PSTv-11 (25.0\%) and PSTv-14 (75.0\%), with very similar virulence or avirulence patterns. Region 5 had seven races, with PSTv-19 (300000) $(33.3 \%)$ as the most frequent race. Region 6 had 13 races, with PSTv-37 (53.0\%) as the most frequent one. From regions 7 to 12 , the number of races ranged from 2 (region 10) to 14 (region 7) and PSTv-37 (45.5 to 66.7\%) was the most frequent race in each region. For comparison of races in the western (regions 1 to 6) and eastern (regions 7 to 12) United States, more races were detected in the western ( 34 races) than in the eastern (15 races) regions (Table 4).

Virulence frequencies and distributions. In 2010, the countrywide percentages of virulences to $\mathrm{Yr} 6, \mathrm{Yr} 7, \mathrm{Yr} 8, \mathrm{Yr} 9, \mathrm{Yr} 17, \mathrm{Yr} 27$, Yr43, Yr44, YrTr1, and YrExp2 among the 348 isolates were high

Table 3. Races and their octal codes, frequencies, distribution, and equivalent old races of Puccinia striiformis f. sp. tritici detected in the United States in 2010

\begin{tabular}{|c|c|c|c|c|c|c|}
\hline $\begin{array}{l}\text { PSTV } \\
\text { race }\end{array}$ & $\begin{array}{l}\text { Octal } \\
\text { code }\end{array}$ & Virulence or avirulence formula on $\mathrm{Yr}$ genes & $N^{\mathbf{a}}$ & $\begin{array}{l}\text { Freq. } \\
(\%)^{b}\end{array}$ & State $(N)^{\text {c }}$ & $\begin{array}{l}\text { Equivalent } \\
\text { old race }^{d}\end{array}$ \\
\hline PSTv-1 & 100000 & $1 / 5,6,7,8,9,10,15,17,24,27,32,43,44$, SP,Exp2,Tr1, Тye & 1 & 0.29 & WA(1) & PST-21 \\
\hline PSTv-2 & 533003 & $1,6,9,17$, Tye $/ 5,7,8,10,15,24,27,32,43,44, \mathrm{SP}, \operatorname{Tr} 1, \operatorname{Exp} 2$ & 3 & 0.86 & WA(3) & PST-144 \\
\hline PSTv-3 & 563203 & $1,6,8,9,17,27$, Tye $/ 5,7,10,15,24,32,43,44$, SP,Tr1,Exp2 & 1 & 0.29 & WA(1) & PST-143 \\
\hline PSTv-4 & 533233 & $1,6,9,17,27, \mathrm{SP}, \mathrm{Tye} / 5,7,8,10,15,24,32,43,44, \operatorname{Tr} 1, \operatorname{Exp} 2$ & 3 & 0.86 & $\mathrm{OR}(1), \mathrm{WA}(2)$ & PST-144 \\
\hline PSTv-5 & 573320 & $1,6,7,8,9,17,27,44 / 5,10,15,24,32,43$, SP,Tr1,Exp2,Tye & 1 & 0.29 & $\mathrm{ID}(1)$ & PST-147 \\
\hline PSTv-6 & 570250 & $1,6,7,8,9,27,43, \mathrm{SP} / 5,10,15,17,24,32,44, \operatorname{Tr} 1, \operatorname{Exp} 2, \mathrm{Tye}$ & 1 & 0.29 & $\mathrm{OR}(1)$ & PST-147 \\
\hline PSTv-7 & 563242 & $1,6,8,9,17,27,43,44, \operatorname{Exp} 2 / 5,7,10,15,24,32, \mathrm{SP}, \operatorname{Tr} 1$,Tye & 1 & 0.29 & $\mathrm{IN}(1)$ & PST-76 \\
\hline PSTv-8 & 173226 & $1,7,8,9,17,27,44, \operatorname{Exp} 2$, Tye $/ 5,6,10,15,24,32,43, \mathrm{SP}, \operatorname{Tr} 1$ & 5 & 1.44 & $\mathrm{CA}(1), \mathrm{OR}(2), \mathrm{WA}(2)$ & PST-142 \\
\hline PSTv-9 & 575223 & $1,6,7,8,9,10,17,27,44$, Tye $/ 5,15,24,32,43, S P, \operatorname{Tr} 1, \operatorname{Exp} 2$ & 1 & 0.29 & WA $(1)$ & PST-138 \\
\hline PSTv-10 & 563256 & $1,6,8,9,17,27,43, \mathrm{SP}, \mathrm{Exp} 2, \mathrm{Tye} / 5,7,10,15,24,44,32, \operatorname{Tr} 1$ & 1 & 0.29 & WA(1) & PST-143 \\
\hline PSTv-11 & 573246 & $1,6,7,8,9,17,27,43,44, \operatorname{Exp} 2$, Tye $/ 5,10,15,24,32, \mathrm{SP}, \operatorname{Tr} 1$ & 61 & 17.53 & $\mathrm{ID}(4), \mathrm{MT}(3), \mathrm{OR}(8), \mathrm{WA}(46)$ & PST-127, PST-139 \\
\hline PSTv-12 & 573047 & $1,6,7,8,9,17,43,44, \operatorname{Tr} 1, \operatorname{Exp} 2, \mathrm{Tye} / 5,10,15,24,27,32, \mathrm{SP}$ & 2 & 0.57 & $\mathrm{CA}(2)$ & PST-127, PST-137 \\
\hline PSTv-13 & 573273 & $1,6,7,8,9,17,27,43,44$, SP,Tye $/ 5,10,15,24,32, \operatorname{Tr} 1, \operatorname{Exp} 2$ & 1 & 0.29 & $\mathrm{WA}(1)$ & PST-143 \\
\hline PSTV-14 & 573247 & $1,6,7,8,9,17,27,43,44, \operatorname{Tr} 1, \operatorname{Exp} 2, \mathrm{Tye} / 5,10,15,24,32, \mathrm{SP}$ & 25 & 7.18 & $\begin{array}{l}\mathrm{CA}(4), \mathrm{ID}(1), \mathrm{MT}(6), \mathrm{OR}(3), \\
\text { WA(11) }\end{array}$ & PST-127, PST-139 \\
\hline PSTV-15 & 553276 & 1,6,7,9,17,27,43,44,SP,Exp2,Tye/5,8,10,15,24,32,Tr1 & 1 & 0.29 & $\mathrm{WA}(1)$ & PST-144 \\
\hline PSTv-16 & 571544 & $1,6,7,8,9,10,24,32,43,44, \operatorname{Tr} 1, \operatorname{Exp} 2 / 5,15,17,27$, SP,Tye & 1 & 0.29 & $\mathrm{CA}(1)$ & PST-151 \\
\hline PSTv-17 & 573276 & $1,6,7,8,9,17,27,43,44, \mathrm{SP}, \operatorname{Exp} 2, \mathrm{Tye} / 5,10,15,24,32, \operatorname{Tr} 1$ & 5 & 1.44 & $\mathrm{WA}(5)$ & PST-137 \\
\hline PSTv-18 & 000000 & $/ 1,5,6,7,8,9,10,15,17,24,27,32,43,44, \mathrm{SP}, \operatorname{Tr} 1, \operatorname{Exp} 2$,Туе & 9 & 2.58 & $\operatorname{MT}(1)$, WA(8) & PST-145 \\
\hline PSTv-19 & 300000 & $6 / 1,5,7,8,9,10,15,17,24,27,32,43,44$, SP,Tr1,Exp2,Tye & 7 & 2.01 & $\mathrm{WA}(7)$ & PST-35 \\
\hline PSTv-20 & 003000 & $17 / 1,5,6,7,8,9,10,15,24,27,32,43,44, \mathrm{SP}, \operatorname{Tr} 1$,Exp2,Тye & 1 & 0.29 & WA(1) & PST-145 \\
\hline PSTv-21 & 303000 & $6,17 / 1,5,7,8,9,10,15,24,27,32,43,44, \mathrm{SP}, \operatorname{Tr} 1, \operatorname{Exp} 2$,Тye & 3 & 0.86 & WA(3) & PST-146 \\
\hline PSTv-22 & 023000 & $8,17 / 1,5,6,7,9,10,15,24,27,32,43,44, S P, T r 1$, Exp2, Tye & 1 & 0.29 & WA(1) & PST-148 \\
\hline PSTv-23 & 001500 & $10,24,32 / 1,5,6,7,8,9,15,17,27,43,44, S P, \operatorname{Tr} 1, \operatorname{Exp} 2$,Тye & 1 & 0.29 & $\mathrm{OR}(1)$ & PST-29 \\
\hline PSTv-24 & 010022 & 7,44,Exp2/1,5,6,8,9,10,15,17,24,27,32,43,SP,Tr1,Tye & 2 & 0.57 & $\mathrm{TX}(2)$ & PST-46 \\
\hline PSTv-25 & 013022 & 7,17,44,Exp2/1,5,6,8,9,10,15,24,27,32,43,SP,Tr1,Tye & 1 & 0.29 & $\mathrm{TX}(1)$ & PST-46 \\
\hline PSTv-26 & 301700 & $6,10,24,27,32 / 1,5,7,8,9,15,17,43,44, \mathrm{SP}, \operatorname{Tr} 1, \operatorname{Exp} 2, \mathrm{Tye}$ & 2 & 0.57 & WA(2) & PST-91, PST-92 \\
\hline PSTv-27 & 005501 & $10,17,24,32, \operatorname{Tr} 1 / 1,5,6,7,8,9,15,27,43,44, \mathrm{SP}, \operatorname{Exp} 2, \mathrm{Tye}$ & 1 & 0.29 & $\mathrm{OR}(1)$ & PST-50 \\
\hline PSTv-28 & 353022 & $6,7,9,17,44, \operatorname{Exp} 2 / 1,5,8,10,15,24,27,32,43$, SP,Tr1,Tye & 1 & 0.29 & $\mathrm{TX}(1)$ & PST-84 \\
\hline PSTv-29 & 313222 & $6,7,17,27,44, \operatorname{Exp} 2 / 1,5,8,9,10,15,24,32,43, \mathrm{SP}, \operatorname{Tr} 1, \mathrm{Tye}$ & 1 & 0.29 & $\mathrm{TX}(1)$ & PST-146 \\
\hline PSTv-30 & 370024 & $6,7,8,9,44, \operatorname{Tr} 1, \operatorname{Exp} 2 / 1,5,10,15,17,24,27,32,43$, SP,Tye & 6 & 1.72 & $\mathrm{CA}(3), \mathrm{MD}(1), \mathrm{ND}(1), \mathrm{TX}(1)$ & PST-80 \\
\hline PSTv-31 & 373024 & $6,7,8,9,17,44, \operatorname{Tr} 1, \operatorname{Exp} 2 / 1,5,10,15,24,27,32,43$, SP,Tye & 5 & 1.44 & $\mathrm{LA}(1), \mathrm{ND}(1), \mathrm{NE}(1), \mathrm{SD}(2)$ & PST-100, PST-102 \\
\hline PSTv-32 & 370044 & $6,7,8,9,43,44, \operatorname{Tr} 1, \operatorname{Exp} 2 / 1,5,10,15,17,24,27,32$, SP,Tye & 6 & 1.72 & $\mathrm{CA}(1), \mathrm{KY}(1), \mathrm{LA}(3), \mathrm{MT}(1)$ & PST-98, PST-100 \\
\hline PSTV-33 & 370224 & $6,7,8,9,27,44, \operatorname{Tr} 1, \operatorname{Exp} 2 / 1,5,10,15,17,24,32,43$, SP,Tye & 5 & 1.44 & $\begin{array}{l}\operatorname{AR}(1), \mathrm{CA}(1), \operatorname{IL}(1), \mathrm{MN}(1), \\
\operatorname{MT}(1)\end{array}$ & PST-100, PST-102 \\
\hline PSTV-34 & 373224 & $6,7,8,9,17,27,44, \operatorname{Tr} 1, \operatorname{Exp} 2 / 1,5,10,15,24,32,43$, SP,Tye & 17 & 4.89 & $\begin{array}{l}\mathrm{CA}(3), \mathrm{KS}(3), \mathrm{MN}(3), \mathrm{MT}(2), \\
\mathrm{ND}(1), \mathrm{OK}(2), \mathrm{TX}(3)\end{array}$ & PST-100 \\
\hline PSTv-35 & 373044 & $6,7,8,9,17,43,44, \operatorname{Tr} 1, \operatorname{Exp} 2 / 1,5,10,15,24,27,32$, SP,Tye & 11 & 3.16 & $\begin{array}{l}\mathrm{CA}(2), \operatorname{IL}(1), \mathrm{MD}(1), \mathrm{NE}(2) \\
\mathrm{OK}(1), \mathrm{SD}(1), \mathrm{TX}(3)\end{array}$ & PST-100 \\
\hline PSTv-36 & 370244 & $6,7,8,9,27,43,44, \operatorname{Tr} 1, \operatorname{Exp} 2 / 1,5,10,15,17,24,32$, SP,Tye & 18 & 5.17 & $\begin{array}{l}\mathrm{CA}(7), \operatorname{DE}(1), \operatorname{ID}(1), \operatorname{IL}(2), \operatorname{LA}(1), \\
\operatorname{MN}(2), \operatorname{MT}(1), \operatorname{TX}(1), \mathrm{WA}(1), \\
\text { WI(1) }\end{array}$ & PST-100, PST-115 \\
\hline PSTv-37 & 373244 & $6,7,8,9,17,27,43,44, \operatorname{Tr} 1, \operatorname{Exp} 2 / 1,5,10,15,24,32, \mathrm{SP}, \mathrm{Tye}$ & 120 & 34.48 & $\begin{array}{l}\mathrm{AR}(10), \operatorname{CA}(35), \operatorname{IL}(3), \mathrm{KS}(11), \\
\mathrm{LA}(4), \operatorname{MN}(5), \operatorname{MT}(1), \mathrm{NC}(1), \\
\mathrm{ND}(9), \operatorname{NE}(3), \mathrm{NY}(2), \mathrm{OK}(5), \\
\mathrm{TX}(19), \mathrm{VA}(4), \mathrm{WA}(6), \mathrm{WI}(2)\end{array}$ & PST-100, PST-131 \\
\hline PSTV-38 & 373444 & $6,7,8,9,17,24,27,43,44, \operatorname{Tr} 1, \operatorname{Exp} 2 / 1,5,10,15,32$, SP,Tye & 3 & 0.86 & $\mathrm{CA}(2), \mathrm{TX}(1)$ & PST-100 \\
\hline PSTv-39 & 375244 & $6,7,8,9,10,17,27,43,44, \operatorname{Tr} 1, \operatorname{Exp} 2 / 1,5,15,24,32$, SP,Tye & 1 & 0.29 & $\mathrm{LA}(1)$ & PST-102 \\
\hline PSTV-40 & 371744 & $6,7,8,9,10,24,27,32,43,44, \operatorname{Tr} 1, \operatorname{Exp} 2 / 1,5,15,17$, SP,Tye & 2 & 0.58 & $\mathrm{CA}(1), \mathrm{WA}(1)$ & PST-114, PST-116 \\
\hline PSTV-41 & 375744 & $6,7,8,9,10,17,24,27,32,43,44, \operatorname{Tr} 1, \operatorname{Exp} 2 / 1,5,15, \mathrm{SP}, \mathrm{Tye}$ & 10 & 2.87 & $\mathrm{CA}(3), \mathrm{ID}(1), \mathrm{UT}(1), \mathrm{WA}(5)$ & PST-116, PST-119 \\
\hline
\end{tabular}


(67.0 to 93.7\%); while virulences to $\operatorname{Yrl}(32.8 \%)$ and YrTye (31.3) were moderate; and virulences to $\mathrm{Yr} 10, \mathrm{Yr} 24, \mathrm{Yr} 32$, and $\mathrm{YrSP}$ were low (3.4 to 5.7\%) (Table 5). More importantly, no virulence to $\operatorname{Yr} 5$ or $\operatorname{Yr} 15$ was detected.

The virulence frequencies varied greatly among the epidemiological regions. Virulences to $\mathrm{Yrl}$ and $\mathrm{YrTye}$ were detected almost exclusively in the western United States (regions 1 to 6) except one isolate with the $\mathrm{Yrl}$ virulence from Indiana (region 11) and two isolates from the eastern Montana (region 9) (Table 5), which may indicate that races with virulence to $Y r 1$ and YrTye were spreading to the east from the west. Even in the western United States, virulence to the two resistance genes was present in all isolates from region 4 (western Oregon) but not in region 5 (northwestern Washington). Similarly, virulences to $\mathrm{Yr} 10$ and $\mathrm{Yr} 24$ were presented in isolates of regions 1, 3, 5, and 6 in the western United States, whereas only one isolate of region 7 in the eastern United States had these virulences. The $\operatorname{Yr} 32$ virulence was only detected in regions 1, 3, 5, and 6 in the west. The $\operatorname{YrSP}$ virulence was found only in region 1, with a low frequency of $5 \%$ in that region. Although virulences to $\mathrm{Yr} 6, \mathrm{Yr} 7, \mathrm{Yr} 8, \mathrm{Yr}$ 9, $\mathrm{Yr} 17, \mathrm{Yr} 27, \mathrm{Yr} 43, \mathrm{Yr} 44, \mathrm{YrTr} 1$, and $Y r E x p 2$ were detected in all regions, their frequencies ranged from $14.3 \%$ in region 5 to $100 \%$ in two or more of the other regions (Table 5). It is worth noting that virulence to $\mathrm{Yrl} 7 \mathrm{had}$ relatively high frequencies (38.1 to $100 \%$ ) across all regions.

\section{Discussion}

Stripe rust in 2010. The 2010 epidemic of wheat stripe rust was the most widespread in U.S. recorded history, including that of $2005(4,13)$. Yield loss due to wheat stripe rust, estimated as $4.36 \%$ or 2.606 million metric tons, was the highest among the four severe epidemics, with yield losses above one million metric tons since 2000 (4,13; (http://iapreview.ars.usda.gov/SP2UserFiles/ad_hoc/

Table 4. Number of collections of wheat stripe rust, number of PSTv races of Puccinia striiformis f. sp. tritici identified, and their frequencies in epidemiological regions in the United States in 2010

\begin{tabular}{lccc}
\hline Region & $\begin{array}{c}\text { Number of } \\
\text { isolates }\end{array}$ & $\begin{array}{c}\text { Number of } \\
\text { races }\end{array}$ & \multicolumn{1}{c}{ PSTv races and frequency $(\%)^{\mathbf{b}}$} \\
\hline R1 & 104 & 21 & $1(1.0), 2(2.9), 3(1.0), 4(3.9), 5(1.0), 6(1.0), 8(3.9), 9(1.0), 10(1.0), 11(50.9), 13(1.0), 14(11.6)$, \\
& & & $15(1.0), 17(4.8), 18(3.9), 23(1.0), 27(1.0), 36(1.0), 37(5.8), 40(1.0), 41(21.9)$ \\
R2 & 16 & 8 & $11(18.8), 14(37.5), 18(6.3), 32(6.3), 33(6.3), 34(12.5), 36(6.3), 37(6.3)$ \\
R3 & 5 & 3 & $11(40.0), 36(20.0), 41(40.0)$ \\
R4 & 4 & 2 & $11(25.0), 14(75.0)$ \\
R5 & 21 & 7 & $18(19.1), 19(33.3), 20(4.8), 21(14.3), 22(4.8), 26(9.5), 41(14.3)$ \\
R6 & 66 & 13 & $8(1.5), 12(3.0), 14(6.1), 16(1.5), 30(4.6), 32(1.5), 34(4.5), 35(3.0), 36(10.6), 37(53.0), 38(4.5)$, \\
& & & $40(1.5), 41(4.6)$ \\
R7 & 62 & 14 & $24(3.2), 25(1.6), 28(1.6), 29(1.6), 30(1.6), 31(1.6), 32(4.8), 33(1.6), 34(8.0), 35(6.5), 36(3.2)$, \\
& & & $37(61.3), 38(1.6), 39(1.6)$ \\
R8 & 22 & 7 & $11(9.1), 31(4.6), 34(13.6), 35(9.1), 37(63.6)$ \\
R9 & 26 & 2 & $30(3.9), 31(11.6), 33(3.9), 34(15.4), 35(3.9), 36(7.7), 37(53.9)$ \\
R10 & 2 & 5 & $7(9.1), 33(9.1), 35(9.1), 36(27.3), 37(45.5)$ \\
R11 & 11 & 4 & $30(11.1), 35(11.1), 36(11.1), 37(66.7)$ \\
R12 & 9 & $\ldots$ & $\ldots$ \\
R1 to R6 & 216 & 15 & $\ldots$ \\
R7 to R12 & 132 & 41 & $\ldots$ \\
The United States & 348 & & \\
\hline
\end{tabular}

${ }^{\text {a }}$ Stripe rust epidemiological regions are as follows: region $1(\mathrm{R} 1)=$ eastern Washington, northeastern Oregon, and northern Idaho; R2 = western Montana and southern Alberta, Canada; R3 = southern Idaho, southeastern Oregon, northern Nevada, northern Utah, western Wyoming, and western Colorado; R4 = western Oregon and northern California; R5 = northwestern Washington and southwestern British Columbia, Canada; R6 = central and southern California, Arizona, and western New Mexico; and R7 = Texas, Louisiana, Arkansas, Oklahoma, and eastern New Mexico; R8 = Kansas, Nebraska, and eastern Colorado; R9 = South Dakota, North Dakota, Minnesota, eastern Montana, and southern Manitoba and southern Saskatchewan, Canada; R10 = Mississippi, Alabama, Florida, Georgia, South Dakota, North Dakota, Tennessee, and Kentucky; R11 = Missouri, Illinois, Indiana, Iowa, Wisconsin, Michigan, and Ontario, Canada; and R12 = Virginia, West Virginia, Ohio, Maryland, Pennsylvania, and New York (13,34). R1 to R 6 are regions west of the Rocky Mountains (the western United States) and R7 to 12 are those east of the Rocky Mountains (the eastern United States).

${ }^{\mathrm{b}}$ PSTv races identified using the 18 yellow rust $(\mathrm{Yr})$ single-gene lines are shown in Table 3 and the most predominant race in each region is shown in italics.

Table 5. Virulence frequencies of Puccinia striiformis f. sp. tritici countrywide and in epidemiological regions in the United States in 2010

\begin{tabular}{|c|c|c|c|c|c|c|c|c|c|c|c|c|c|c|}
\hline \multirow[b]{2}{*}{ Virulence } & \multicolumn{2}{|c|}{ Countrywide $^{a}$} & \multicolumn{12}{|c|}{ Frequency $(\%)$ in epidemiological regions ${ }^{b}$} \\
\hline & $N$ & Freq. $(\%)$ & $\mathbf{R} \mathbf{1}$ & $\mathbf{R 2}$ & $\mathbf{R 3}$ & $\mathbf{R 4}$ & R5 & R6 & $\mathbf{R 7}$ & $\mathbf{R 8}$ & R9 & R10 & R11 & R12 \\
\hline Yrl & 114 & 32.8 & 84.6 & 47.4 & 40.0 & 100.0 & 0.0 & 12.1 & 0.0 & 0.0 & 7.7 & 0.0 & 9.1 & 0.0 \\
\hline $\operatorname{Yr} 5$ & 0 & 0 & 0.0 & 0.0 & 0.0 & 0.0 & 0.0 & 0.0 & 0.0 & 0.0 & 0.0 & 0.0 & 0.0 & 0.0 \\
\hline Yr6 & 326 & 93.7 & 89.4 & 93.8 & 100.0 & 100.0 & 71.4 & 98.5 & 95.2 & 100.0 & 100.0 & 100.0 & 100.0 & 100.0 \\
\hline$Y r 7$ & 313 & 89.9 & 85.6 & 93.8 & 100.0 & 100.0 & 14.3 & 100.0 & 100.0 & 100.0 & 100.0 & 100.0 & 90.9 & 100.0 \\
\hline$Y r 8$ & 311 & 89.4 & 86.6 & 93.8 & 100.0 & 100.0 & 19.0 & 100.0 & 91.9 & 100.0 & 100.0 & 100.0 & 100.0 & 100.0 \\
\hline$Y r 9$ & 318 & 91.4 & 93.3 & 93.8 & 100.0 & 100.0 & 14.3 & 100.0 & 94.5 & 100.0 & 100.0 & 100.0 & 100.0 & 100.0 \\
\hline Yr10 & 19 & 5.5 & 5.8 & 0.0 & 40.0 & 0.0 & 23.8 & 7.6 & 1.6 & 0.0 & 0.0 & 0.0 & 0.0 & 0.0 \\
\hline Yr15 & 0 & 0 & 0.0 & 0.0 & 0.0 & 0.0 & 0.0 & 0.0 & 0.0 & 0.0 & 0.0 & 0.0 & 0.0 & 0.0 \\
\hline Yr17 & 285 & 82.5 & 91.3 & 75.0 & 80.0 & 100.0 & 38.1 & 78.8 & 82.3 & 100.0 & 84.6 & 50.0 & 63.6 & 77.8 \\
\hline Yr24 & 20 & 5.7 & 4.8 & 0.0 & 40.0 & 0.0 & 23.8 & 10.6 & 1.6 & 0.0 & 0.0 & 0.0 & 0.0 & 0.0 \\
\hline $\operatorname{Yr} 27$ & 285 & 82.2 & 89.4 & 87.5 & 100.0 & 100.0 & 23.8 & 86.4 & 79.0 & 86.4 & 80.8 & 50.0 & 90.9 & 77.8 \\
\hline Yr32 & 16 & 4.9 & 3.8 & 0.0 & 40.0 & 0.0 & 23.8 & 7.6 & 0.0 & 0.0 & 0.0 & 0.0 & 0.0 & 0.0 \\
\hline Yr43 & 259 & 77.6 & 80.8 & 75.0 & 100.0 & 100.0 & 14.3 & 84.8 & 72.6 & 72.7 & 61.5 & 100.0 & 81.8 & 77.8 \\
\hline Yr44 & 313 & 89.9 & 84.6 & 93.8 & 100.0 & 100.0 & 14.3 & 100.0 & 100.0 & 100.0 & 100.0 & 100.0 & 100.0 & 100.0 \\
\hline $\mathrm{YrSP}$ & 12 & 3.4 & 5.0 & 0.0 & 0.0 & 0.0 & 0.0 & 0.0 & 0.0 & 0.0 & 0.0 & 0.0 & 0.0 & 0.0 \\
\hline YrTr1 & 233 & 67.0 & 22.1 & 75.0 & 60.0 & 75.0 & 14.3 & 98.5 & 91.9 & 90.9 & 100.0 & 100.0 & 90.9 & 100.0 \\
\hline YrExp2 & 315 & 89.4 & 85.6 & 93.8 & 100.0 & 100.0 & 14.3 & 100.0 & 100.0 & 100.0 & 100.0 & 100.0 & 100.0 & 100.0 \\
\hline YrTye & 109 & 31.3 & 81.7 & 56.3 & 40.0 & 100.0 & 0.0 & 10.6 & 0.0 & 0.0 & 7.7 & 0.0 & 0.0 & 0.0 \\
\hline
\end{tabular}

${ }^{\mathrm{a}} \mathrm{N}=$ number of isolates and Freq. = frequency.

${ }^{\mathrm{b}}$ See Figure 1 and Table 4 for the regions. 
36400500Smallgrainlossesduetorust/SmalGraiSu-09-30-2010_ new_format.pdf and http://striperust.wsu.edu/generalInformation/ puccinia-striiformis-impacts.html). Additional economic effects of this disease included costs associated with wide application of fungicides. The disease was especially severe in the Great Plains states and states west of the Rocky Mountains. Although the changes in races and resistance in some cultivars could be attributed to the 2010 epidemic, weather conditions played an important role. In the states east of the Rocky Mountains, the relatively warm weather during the 2009-10 winter allowed a high level of winter survival and early development of stripe rust in southern states. The onset of stripe rust development before March in Texas of region 7 likely indicates a severe and widespread epidemic in this region and other regions east of the Rocky Mountains (13). The long period of cool and wet weather conditions in the spring and early summer in the Great Plains states was extremely favorable to the development and spread of stripe rust. The lower temperatures and higher-than-normal precipitation in May and June, which allowed P. striiformis f. sp. tritici to infect wheat crops every night and did not allow HTAP resistance to be well expressed, contributed to the severe stripe rust epidemic in the Pacific Northwest states.

Selection of $\mathrm{Yr}$ single-gene lines to establish a new set of differentials for identification of $\boldsymbol{P}$. striiformis $\mathbf{f}$. sp. tritici races. Different $P$. striiformis $\mathrm{f}$. $\mathrm{sp}$. tritici race identification systems used in different regions and countries of the world $(3,31,38)$ make it difficult to compare races in different countries. Differential cultivars with two or more genes also make it difficult to identify virulence to a particular resistance gene. Wellings et al. (37) developed stripe-rust-resistant NILs to monitor virulences in the $P$. striiformis f. sp. tritici populations throughout the world. However, most of these lines have not been used as differentials to identify races. For various reasons, there have been only a few virulence studies to compare $P$. striiformis f. sp. tritici populations from different countries $(30,40)$. To better characterize the $P$. striiformis f. sp. tritici races, 18 wheat lines carrying only one known stripe rust resistance gene were selected and tested with $P$. striiformis $\mathrm{f}$. sp. tritici isolates collected in 2010. The data indicate that the new set of $18 \mathrm{Yr}$ single-gene lines is useful in differentiating races in the $P$. striiformis $\mathrm{f}$. sp. tritici population.

The big advantage of the single-gene line differentials over the previous cultivar or line differentials is to provide clearer information about virulence to specific individual resistance genes. The new set of differentials detected $5.5 \%$ of the isolates having virulence to $\mathrm{Yr} 10$ while the old set with Moro (YrIO and YrMor) detected $4.3 \%$ of the isolates. The $Y r 17$ single-gene line identified its virulence at a much higher frequency, $82.5 \%$, than Hyak ( $Y r 17$ and YrTye) at $31.3 \%$. Similarly, the $\operatorname{YrTr} 1$ line identified $55.5 \%$ more isolates than Tres ( $Y r \operatorname{Tr} 1$ and $Y r T r 2)$ having the $Y r \operatorname{Tr} 1$ virulence; and the $\operatorname{YrExp} 2$ line identified $14.7 \%$ more isolates than 'Express' (YrExp1 and YrExp2). Furthermore, the new differential set provides virulence information for $Y r 24, Y r 27, \operatorname{Yr} 32, \operatorname{YrSP}, \mathrm{Yr} 43$, and $Y r 44$, which are more important than some genes or combinations of the genes in old cultivar differentials such as Paha (YrPal, $Y r P a 2$, and $Y r P a 3)$, 'Druchamp' (Yr3a, YrD, and YrDru), 'Produra' (YrPrl and YrPr2), Yamhill (Yr2, Yr4a, and YrYam), Stephens ( $Y r 3 a, Y r S$, and $Y r S t e)$, and 'Fielder' (Yr6 and $Y r 20)$. The missing information by the new set can be obtained by testing isolates of new PSTv races on the old differentials, as we did in the present study.

Yrl is an important gene for distinguishing races in the $P$. striiformis f. sp. tritici populations before $2000(3,13,22,24)$ and in recent years in the United States, as well as for populations in other countries $(30,31,40)$. 'AvsYr1NIL' $(Y r l)$ and its donor, 'Chinese 166 ' $(Y r 1)$ that has been used in the previous U.S. differential set (3) and the "World" differential set (16,31), produced identical results in the present study and a previous study (30). The $Y r l$ NIL clearly separated the 41 races detected in the present study into $\mathrm{Yr} 1$ virulence group (PSTv-1 to PSTv-17) and avirulent race group (PSTv-18 to PSTV-41) (Table 3).
The inclusion of $\operatorname{Yr} 5$ and $\operatorname{Yr} 15$ was based on their importance in breeding programs. $Y r 5$ and $Y r 15$ have been widely used in the breeding programs in recent years in the United States and other countries. To date, these two genes were effective toward all of the isolates evaluated in this study and previous studies of $P$. striiformis f. sp. tritici populations from the United States and other countries $(3,4,12,13,30,34,40)$. Isolates virulent to $\operatorname{Yr} 5$ have been reported in India and Australia and isolates virulent to $\mathrm{Yr} 15$ has been reported in Afghanistan (26). Although virulence to these genes have not been detected in the United States, it is important to include these genes in the differentials for identification of potential races virulent to these genes in the future.

Resistance genes $Y r 6, Y r 7, Y r 8, Y r 9, Y r 10, Y r 17, Y r 24, Y r 27$, and $Y r 32$ are important internationally. Including these genes should allow the comparison of $P$. striiformis f. sp. tritici races in the United States and other countries in different time periods (30). Most of these $\mathrm{Yr}$ gene lines produced distinct avirulent (ITs 1 to 2) and virulent (ITs 8 to 9) phenotypes. Although lines with $\operatorname{Yr} 17$ or $Y r 27$ sometimes produced intermediate ITs (ITs 4 to 6), which are not ideal for use as differentials, these genes are important in the recent epidemics in different countries of the world. The sources of Yr17 resistance ('VPM1', Hyak, and 'Madsen') have been used in the wheat breeding programs in the Pacific Northwest since the 1980s and, more recently, in the eastern United States. Virulence to Hyak ( $Y r 17$ and YrTye) were first detected in the United States in $1990(22,23)$ and, more recently, in 2007 (13), indicating the existence of $\operatorname{Yr} 17$ virulence. In this study, $82.5 \%$ of the P. striiformis $\mathrm{f}$. sp. tritici isolates collected from all 12 epidemic regions in 2010 had the $\operatorname{Yr} 17$ virulence. However, using the old set of differentials, including Hyak, only $31.33 \%$ of the isolates in the western United States and $0.29 \%$ of the isolates in the eastern United States were identified to have virulence to Hyak and, therefore, $\operatorname{Yr} 17$ in 2010 (data not shown). The high frequency and wide distribution of the $\mathrm{Yr} 17$ virulence detected in 2010 indicate that it was presented in the $P$. striiformis f. sp. tritici population in the United States especially in the eastern United States for a long time, likely resulted from selection by many wheat cultivars with $\operatorname{Yr} 17$ grown in the United States. Our further studies using the new set of differentials in testing isolates in the past confirmed this conclusion (X. M. Chen, A. M. Wan, and T. L. Liu, unpublished data).

Although $\mathrm{Yr} 27$ may have not been used as extensively as $\mathrm{Yr} 17$ in the United States, the frequency of the $Y r 27$ virulence in the 2010 P. striiformis f. sp. tritici population was also very high $(82.2 \%)$. From other tests, the $\mathrm{Yr} 27$ virulence was found to be present in an isolate of PST-14 as early as 1976 and it was also present in many PST races identified after 2000 (A. M. Wan and X. M. Chen, unpublished data). Moreover, P. striiformis f. sp. tritici populations with the $Y r 27$ virulence have caused epidemics in many other countries, with frequencies of $76 \%$ in Nepal and $83 \%$ in Pakistan and Turkey (30). Therefore, including $Y r 27$ in the new differential set will allow us to understand the evolution and migration of the $P$. striiformis f. sp. tritici populations worldwide.

The lines with Yr43, Yr44, YrSP, YrTr1, YrExp2, and YrTye were selected for inclusion in the new set of differentials mainly because of their high differential ability and their importance in the United States. The $\mathrm{Yr} 43$ and $\mathrm{Yr} 44$ lines were recombinant inbred lines, developed from crosses of United States wheat 'IDO377s' and 'Zak' with 'Avocet Susceptible' (AvS), respectively (14,33). The frequencies of virulence to $\mathrm{Yr} 43$ and $\mathrm{Yr} 44$ were high (77.6 and $89.9 \%$, respectively) in 2010 and present in major races identified after 2000 but either absent (for Yr43) or at a low frequency before 2000 (X. M. Chen, A. M. Wan, and T. L. Liu, unpublished data). The NIL with $\operatorname{YrSP}$ was selected to be included in the new set of differentials because it had very clear reactions (either highly resistant or highly susceptible) when tested with $P$. striiformis f. sp. tritici isolates. Before 2010, the $\operatorname{YrSP}$ line and its donor, 'Spaldings Prolific', were highly resistant in our field nurseries and in greenhouse tests with predominant PST races identified before 2010 (8). The present study is the first report of the $\mathrm{YrSP}$ virulence in the United States, with a frequency of $3.4 \%$ and only detected in re- 
gion 1. Isolates obtained after 2010 indicated that the $\operatorname{YrSP}$ virulence has increased in frequency (A. M. Wan and X. M. Chen, unpublished data). Virulence to Spaldings Prolific, which has been used in the European set of differentials, was reported in many other countries in the late 1960 s and early 1970 s $(26,32)$. In a recent study, virulence to $\mathrm{YrSP}$ was found in isolates from China, Turkey, and Uzbekistan (30).

The NIL $Y r T r 1$ was developed from backcrossing of Tres to AvS (37). Tres, with two genes, was used in the previous differential set for identifying races in the United States $(3,6,13)$. In the present study, the $\operatorname{YrTr} 1$ virulence had a high frequency (67.0\%) and was present in all epidemiological regions. The $\operatorname{YrExp} 2$ line is a recombinant inbred line developed from a cross between AvS and Express that was included in the previous set of differentials $(3,20)$. The frequency of isolates virulent to $\operatorname{YrExp} 2$ was $89.4 \%$ in 2010 . The $\operatorname{YrExp} 2$ virulence was detected in some of the major races before 1998, while virulence on Express, which has YrExpl and YrExp2 (20,21), was first detected in 1998 (3,12). The YrExpl line was not included in the differential because almost all tested isolates are virulent to this gene (20).

Tyee, with a single gene $\operatorname{YrTye}(7,8,11)$, was used in the previous differential set $(3,24)$. This gene, which is in many wheat cultivars that have been grown in the U.S. Pacific Northwest, is able to differentiate important races that have been mostly restricted in the Pacific Northwest, as shown in the previous and present studies $(13,34)$. Isolates with virulence to YrTye were detected in 10 countries with a moderate $(42 \%)$ frequency (30). Therefore, inclusion of this gene in the new differential set distinguishes not only U.S. races but also international isolates. Mapping studies are undergoing for $Y r S P, Y r T r 1, Y r E x p 2$, and $Y r T y e$ in order to have official $Y r$ names for these genes.

It is not practical to use all individual $Y r$ genes or their combinations, including the previous set of differentials used in the United States $(3,10)$, the World and "European" sets $(5,31)$, the Chinese set $(2,40)$, even some of the $Y r$ single-gene lines used in a recent study (30), and recently identified new genes $(19,27,39)$. The selected $18 \mathrm{Yr}$ genes should provide reasonably good information for identifying races and race groups for monitoring virulence changes. The virulence data on the supplementary differentials and the old U.S. cultivar differentials for isolates representing each of the PSTv races can provide additional information for comparison with historical races and races in other countries. The new set of $Y r$-gene-line differentials is an open-ended system and important $Y r$ genes can be added in the future.

Naming races. Various systems have been used to designate races of the rust pathogens. The number system, which names races with numbers and usually in a sequential order, is the oldest and still widely used. Races of $P$. striiformis f. sp. tritici in China, India, and the United States have been named using numbers $(2,3,13,31,35)$. In the present study, we used the number system for naming the $P$. striiformis $\mathrm{f}$. sp. tritici races in numbers with a prefix of "PSTv" to keep race names simple for easy communication and to keep tracking races. We employed an octal system to code the virulence or avirulence patterns. Similar to the letter coding system, the octal coding system also divides the $\mathrm{Yr}$ gene differentials into groups, with three differentials in a group to keep a single-digit number for each of the possible virulence or avirulence patterns in a group. The octal codes can indicate virulence or avirulence patterns and relationships of race groups. The digitalized naming system has advantages over any simple number system and the letter system for computerized data management and analyses of a large number of races. For example, race 100000 (PSTv-1) is more virulent than 000000 (PSTv-18) and 375744 (PSTv-41 has more virulences than 100000. Races that share the same numbers at some of the six positions are more related by virulence than those with different numbers.

Races in 2010. The major objectives of race analysis are to identify new races and determine distribution and frequencies of races. Because the present study was the first time we used the new set of $\mathrm{Yr}$ single-gene differentials, we could not clearly tell which PSTv races are new. However, by matching equivalent PSTv and PST races (data not shown), nine races (PSTv-2, PSTv-3, PSTv-4, PSTv-6, PSTv-8, PSTv-10, PSTv-13, PSTv-15, and PSTv-21) were possibly new. It would be very time consuming to clearly determine whether they were new for 2010 because all previous isolates need to be tested with the new set of differentials. In fact, we are recovering historical isolates kept in our program and testing them with the new set of differentials and molecular markers. These data should provide information about virulence and race changes in the past half-century in the United States and shed light on mechanisms of the pathogen evolution.

In the present study, we identified PSTv-37 as the most frequent and widely distributed race in 2010 . Similar to the previous results $(3,13,34)$, we found more races in the western than in the eastern United States As discussed before $(13,34)$, more races in the western United States population are due to the more favorable weather conditions, cropping systems, and a large number of cultivars with different types of resistance and diverse resistance genes. Breeding programs must pay attention to the predominant races, and to the races with more virulences, such as PSTv-14, PSTv-40, and PSTv41. We have selected five PSTv races, four (PSTv-14, PSTv-18, PSTv-37, and PSTv-40) from 2010 and one (PSTv-51; 575777) from 2011 (A. M. Wan and X. M. Chen, unpublished), for the routine screening of wheat germplasm for resistance to stripe rust.

\section{Acknowledgments}

This study was supported by the United States Department of AgricultureAgricultural Research Service (Project Number 5348-22000-015-00D), Washington Wheat Commission, and Idaho Wheat Commission. We thank the following collaborators for collecting and sending samples of stripe rust in 2010: Z. Abate, M. Acevedo, R. Baylis, B. Beahm, G. Bergstrom, R. Bowden, C. Bradley, E. Brennan, R. Bruggeman, M. Burrows, K. Campbell, O. Cantu, G. Cisar, D. Clark, J. Costa, E. De Wolf, K. Evans, R. French, C. Griffey, S. Guy, S. Harrison, P. Hayes, R. Herrington, D. Hole, D. Holen, L. Hou, Y. Jin, Y. Liu, D. Long, I. Lowe, D. Marshall, J. Marshall, E. Milus, R. Morton, C. Mundt, B. Olson, B. Padgett, A. Phibbs, S. Reinertsen, P. Reisenauer, K. Richardson, K. Shantz, L. Skoglund, R. Stougaard, M. Wang, S. Wegulo, C. Whaley, J. Wiersma, D. Wood, and X. Zhou; and R. Line and E. Milus for critical review of the manuscript.

\section{Literature Cited}

1. Andrivon, K. D., and de Vallavieille-Pope, C. 1995. Race diversity and complexity in selected populations of fungal biotrophic pathogens of cereals. Phytopathology 85:897-905.

2. Chen, W. Q., Wu, L. R., Liu, T. G., Xu, S. C., Jin, S. L., Peng, Y. L., and Wang, B. T. 2009. Race dynamics, diversity, and virulence evolution in Puccinia striiformis f. sp. tritici, the causal agent of wheat stripe rust in China from 2003 to 2007. Plant Dis. 93:1093-1101.

3. Chen, X. M. 2005. Epidemiology and control of stripe rust [Puccinia striiformis f. sp. tritici] on wheat. Can. J. Plant Pathol. 27:314-337.

4. Chen, X. M. 2007. Challenges and solutions for stripe rust control in the United States. Aust. J. Agric. Res. 58:648-655.

5. Chen, X. M., Jones, S. S., and Line, R. F. 1996. Chromosomal location of genes for resistance to Puccinia striiformis in seven wheat cultivars having resistance genes at $\mathrm{Yr} 3$ and $\mathrm{Yr} 4$ loci. Phytopathology 86:1228-1233.

6. Chen, X. M., and Line, R. F. 1992. Genes for resistance to stripe rust in 'Tres' wheat. Crop Sci. 32:692-696.

7. Chen, X. M., and Line, R. F. 1992. Inheritance of stripe rust resistance in wheat cultivars used to differentiate races of Puccinia striiformis in North America. Phytopathology 82:633-637.

8. Chen, X. M., and Line, R. F. 1992. Identification of stripe rust resistance genes in wheat cultivars used to differentiate North American races of Puccinia striiformis. Phytopathology 82:1428-1434.

9. Chen, X. M., and Line, R. F. 1993. Inheritance of stripe rust resistance in wheat cultivars postulated to have resistance genes at $Y r 3$ and $Y r 4$ loci. Phytopathology 83:382-388.

10. Chen, X. M., Line, R. F., and Jones, S. S. 1995. Chromosomal location of genes for stripe rust in spring wheat cultivars Compair, Fielder, Lee, and Lemhi and interactions of anueploid wheats with races of Puccinia striiformis. Phytopathology 85:375-381.

11. Chen, X. M., Line, R. F., and Jones, S. S. 1995. Chromosomal location of genes for resistance to Puccinia striiformis in winter wheat cultivars Heines VII, Clement, Moro, Tyee, Tres, and Daws. Phytopathology 85:1362-1367.

12. Chen, X. M., Moore, M., Milus, E. A., Long, D. L., Line, R. F., Marshall, D., and Jackson, L. 2002. Wheat stripe rust epidemics and races of Puccinia striiformis f. sp. tritici in the United States in 2000. Plant Dis. 86:39-46.

13. Chen, X. M., Penman, L., Wan, A. M., Cheng, P. 2010. Virulence races of Puccinia striiformis f. sp. tritici in 2006 and 2007 and development of wheat stripe rust and distributions, dynamics, and evolutionary relationships 
of races from 2000 to 2007 in the United States. Can. J. Plant Pathol. 32:315-333.

14. Cheng, P., and Chen, X. M. 2010. Molecular mapping of a gene for stripe rust resistance in spring wheat cultivar IDO377s. Theor. Appl. Genet. 121:195-204

15. Jin, Y., Szabo, L. J., Rouse, M. N., Fetch, T., Jr., Pretorius, Z. A., Wanyera, R., and Njau, P. 2009. Detection of virulence to resistance gene Sr36 within the TTKS race lineage of Puccinia graminis f. sp. tritici. Plant Dis. 93:367370.

16. Johnson, R., Stubbs R., Fuchs, E., and Chamberlain, N. 1972. Nomenclature for physiologic races of Puccinia striiformis infecting wheat. Trans. Br. Mycol. Soc. 58:475-480.

17. Kolmer, J. A., Chen, X. M., and Jin, Y. 2009. Diseases which challenge global wheat production - the wheat rusts. Pages 89-124 in: Wheat: Science and Trade. B. F. Carver, ed. Wiley-Blackwell, John Wiley \& Sons, Inc., Publication, Ames, IA.

18. Kolmer, J. A., Long, D. L., and Hughes, M. E. 2007. Physiological specialization of Puccinia triticina on wheat in the United States in 2005. Plant Dis. 91:979-984.

19. Li, Q., Chen, X. M., Wang, M. N., and Jing, J. X. 2010. Yr45, a new wheat gene for stripe rust resistance mapped on the long arm of chromosome $3 \mathrm{D}$. Theor. Appl. Genet. 122:189-197.

20. Lin, F., and Chen, X. M. 2008. Molecular mapping of genes for race-specific overall resistance to stripe rust in wheat cultivar Express. Theor. Appl. Genet. 116:797-806.

21. Lin, F., and Chen, X. M. 2009. Quantitative trait loci for non-race-specific, high-temperature adult-plant resistance to stripe rust in wheat cultivar Express. Theor. Appl. Genet. 118:631-642.

22. Line, R. F. 2002. Stripe rust of wheat and barley in North America: A retrospective historical review. Annu. Rev. Phytopathol. 40:75-118.

23. Line, R. F., and Chen, X. M. 1996. Wheat and barley stripe rust in North America. Proc. Eur. Mediterr. Cereal Rusts Powdery Mildew Conf. 9:101104.

24. Line, R. F., and Qayoum, A. 1992. Virulence, aggressiveness, evolution, and distribution of races of Puccinia striiformis (the cause of stripe rust of wheat) in North America, 1968-87. U. S. Dep. Agric. Agric. Res. Serv. Tech. Bull. 1788.

25. Line, R. F., Sharp, E. L., and Powelson, R. L. 1970. A system for differentiating races of Puccinia striiformis in the United States. Plant Dis. Rep. 54:992-994.

26. McIntosh, R. A., Wellings, C. R., and Park, R. F. 1995. Wheat Rusts: An Atlas of Resistance Genes. CSIRO Publications, Victoria, Australia.

27. Ren, R. S., Wang, M. N., Chen, X. M., and Zhang, Z. J. 2012. Characterization and molecular mapping of Yr52 for high-temperature adult-plant resistance to stripe rust in spring wheat germplasm PI 183527. Theor. Appl. Genet. 125:847-857.

28. Roelfs, A. P. 1985. Wheat and rye stem rust. Pages 3-37 in: The Cereal
Rusts, Vol. II. Diseases, Distribution, Epidemiology, and Control. A. P. Roelfs and W. R. Bushnell, eds. Academic Press, Orlando, FL.

29. Samborski, D. J. 1985. Wheat leaf rust. Pages 39-59 in: The Cereal Rusts, Vol. II. Diseases, Distribution, Epidemiology, and Control. A. P. Roelfs and W. R. Bushnell, eds. Academic Press, Orlando, FL.

30. Sharma-Poudyal, D., Chen, X. M., Wan, A. M., Zhan, G. M., Kang, Z. S. Cao, S. Q., Jin, S. L., Morgounov, A., Akin, B., Mert, Z., Shah, S. J. A., Bux, H., Ashraf, M., Sharma, R. C., Madariaga, R., Puri, K. D., Wellings, C., Xi, K. Q., Manninger, K., Wanyera, R., Ganzález, M. I., Koyda M. Sanin, S., and Patzek, L. J. 2013. Virulence characterization of international collections of the wheat stripe rust pathogen, Puccinia striiformis f. sp. tritici. Plant Dis. 97:379-386.

31. Stubbs, R. W. 1985. Stripe rust. Pages 61-101 in: The Cereal Rusts, Vol. II. Diseases, Distribution, Epidemiology, and Control. A. P. Roelfs and W. R. Bushnell, eds. Academic Press, Orlando, FL.

32. Stubbs, R. W., Fuchs, E., Vecht, H., and Basset, E. J. W. 1974. The international survey of factors of virulence of Puccinia striiformis Westend. in 1969, 1970 and 1971. Technische Bericht Nr. 21, Nederlands Graan-Centrum, Wageningen, The Netherlands.

33. Sui, X. X., Wang, M. N., and Chen, X. M. 2009. Molecular mapping of a stripe rust resistance gene in spring wheat cultivar Zak. Phytopathology 99:1209-1215.

34. Wan, A. M., and Chen, X. M. 2012, Virulence, frequency, and distribution of races of Puccinia striiformis f. sp. tritici and P. striiformis f. $\mathrm{sp}$. horde identified in the United States in 2008 and 2009. Plant Dis. 96:67-74.

35. Wan, A. M., Zhao, Z. H., Chen, X. M., He, Z. H., Jin, S. L., Jia, Q. Z., Yao, G., Yang, J. X., Wang, B. T., Li, G. B., Bi, Y. Q., and Yuan, Z. Y. 2004. Wheat stripe rust epidemics and virulence of Puccinia striiformis f. sp. tritici in China in 2002. Plant Dis. 88:896-904.

36. Wellings, C. R. 2011. Global status of stripe rust: A review of historical and current threats. Euphytica 179:129-141.

37. Wellings, C. R., Singh, R. P., McIntosh, R. A., and Pretorius, Z. A. 2004 The development and application of near isogenic lines for the stripe (yellow) rust pathosystem. In: Proc. 11th Intl. Cereal Rusts and Powdery Mildew Conf., Norwich, England, Abstr. A1.39, Cereal Rusts and Powdery Mildews Bull. www.crpmb.org/icrpmc11/abstracts.htm

38. Wellings, C. R., Wright, D. G., Keiper. F., and Loughman, R. 2003. First detection of wheat stripe rust in Western Australia, evidence for a foreign incursion. Aust. Plant Pathol. 32:321-322.

39. Xu, L. S., Wang, M. N., Cheng, P., Kang, Z. S., Hulbert, S. H., and Chen, X M. 2012. Molecular mapping of Yr53, a new gene for stripe rust resistance in durum wheat accession PI 480148 and its transfer to common wheat. Theor. Appl. Genet. 126:523-533.

40. Zhan, G. M., Chen, X. M., Kang, Z. S., Huang, L. L., Wang, M. N., Wan, A M., Cheng, P., Cao, S. Q., and Jin, S. L. 2012. Virulence and molecular comparison of Puccinia striiformis $\mathrm{f}$. sp. tritici populations in China and the United States. Fungal Biol. 116:643-653. 